\title{
Maiko-Tayna-Kahuzi-Biega Landscape
}

\author{
Raphael Ngeleza
}

\section{Introduction}

A vast 10 million hectares, the Maiko-Tayna-Kahuzi-Biega landscape is found in the eastern part of the Democratic Republic of the Congo. It covers $90000 \mathrm{~km}^{2}$ of forest and is made up of the National Park of Kahuzi-Biega, a UNESCO World Heritage site since 1980, the National Park of Maiko, the community natural reserves of Tayna and Kisimba-lkobo in the northeast, the natural reserve of Itombwe in the southeast, and the hunting domain of Lwama in the southeast. These protected areas represent approximately 27 percent of the landscape.

Tourism activities centered on gorillas are developed in the National Park of Kahuzi-Biega.

\section{Population}

The main ethnic groups found here are:

- Twa (Pygmies) - local and usually marginalised people

- $\quad$ Bantous - Nande, Pere, Hunde, Nyanga, Rega, Kwame, Kumu, Shi, Bembe, Fuliru, Vira, Nyindu, Tembo, etc.

\section{Vegetation}

The main part of the landscape is covered by dense forest, dry land, mountain forests, bamboo forests, low altitude forests, afroalpine forests, a vast Carex swampy area, and mixed and mono-dominant forests (Uapaca forest), etc.

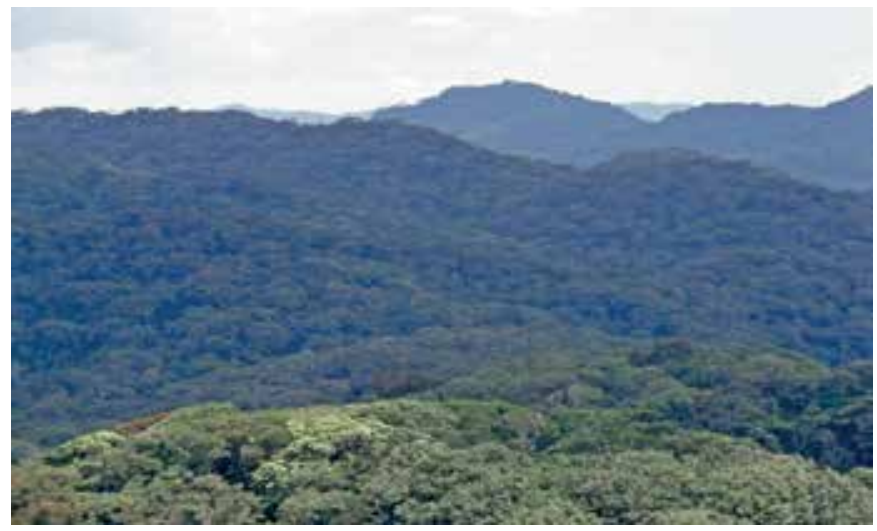

Forests of the Maiko-Tayna-Kahuzi-Biega Landscape

Source: Staff at the National Park of Kahuzi-Biega, Congolese Wildlife Authority (ICCN-PNKB)

\section{Deforestation}

The rate of deforestation in the landscape is estimated at 0.88 percent, i.e. $804 \mathrm{~km}^{2}$ per year. Peri-urban zones are increasingly threatened because of the energy deficit in the region, and increasing demand for timber for construction.

Deforestation has also accelerated because of the influx of refugees from Rwanda and Burundi as a result of the conflicts that have affected the Great Lakes region since 1994.

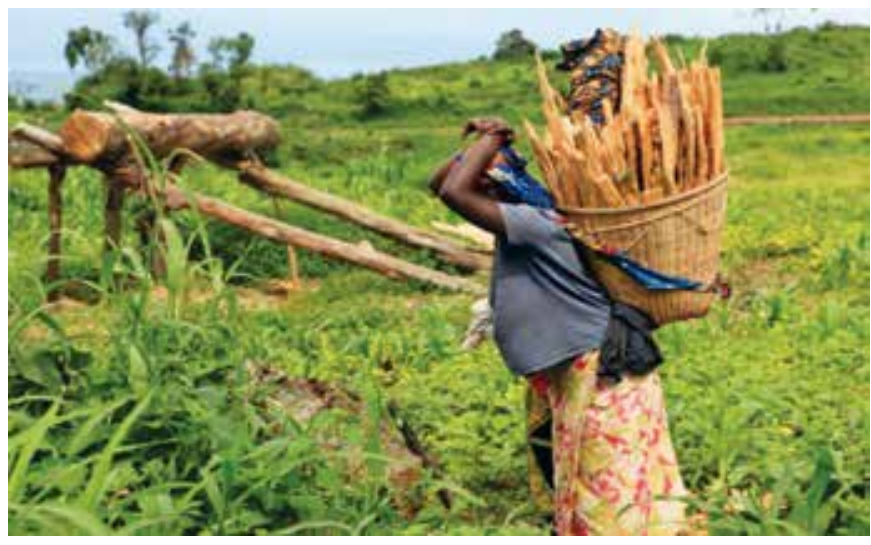

A woman carrying wood - the main energy source for families Source: Staff at the National Park of Kahuzi-Biega, Congolese Wildlife Authority (ICCN-PNKB)

\section{Biodiversity}

In addition to the floral biodiversity, the fauna found in the landscape is abundant and made up of a variety of species, including great apes (gorillas, chimpanzees), small monkeys (colobus, baboons, etc.), great mammals (elephants, okapi, bongo antelopes, buffalo, hylocheres, potamocheres, etc.), birds (pao of the Congo, turacco, grey parrots) and a great variety of reptiles and amphibians.

\section{Threats}

Biodiversity conservation is exposed to recurring potential threats, including the presence of residual armed gangs in and around the landscape, slash-and-burn agriculture, small-scale and industrial mining, poaching (illegal subsistence and commercial hunting, charcoal production, etc.), the lack of official boundaries in most protected areas, soaring demographics, and extreme poverty of the people in the surrounding protected areas (who earn less than US\$1 a day) who rely on natural resources for their survival.

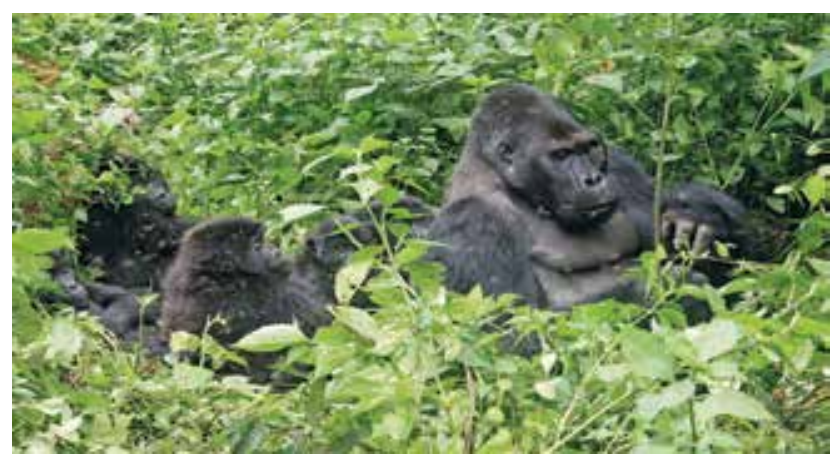

Gorillas are some of the great apes found in the Maiko-Tayna-KahuziBiega Landscape

Source: Staff at the National Park of Kahuzi-Biega, Congolese Wildlife Authority (ICCN-PNKB) 


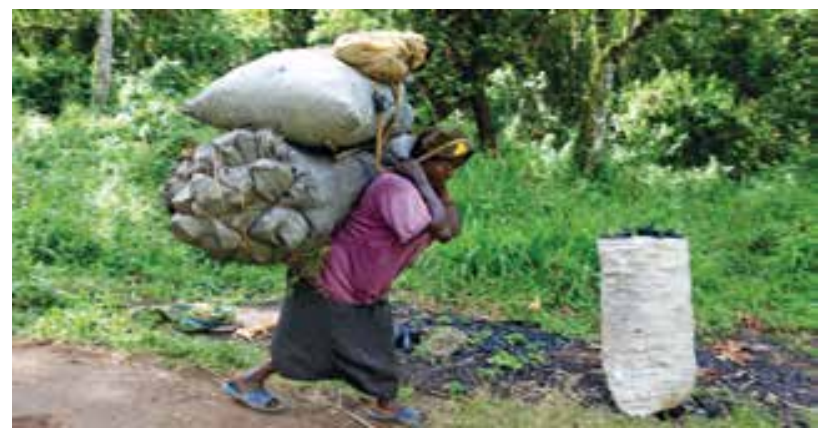

Commercialisation of charcoal constitutes a revenue source for the populations in the landscape

Source: Staff at the National Park of Kahuzi-Biega, Congolese Wildlife Authority (ICCN-PNKB)

It is important to note that the conservation of natural resources has been the trigger of many conflicts that have occurred between local communities and the managers of protected areas. People have been injured on both sides. These conflicts are due to limited access to resources and the fact that local populations fail to perceive the benefits of conservation in their daily lives.

\section{Land use}

No certified forest concessions exist in the landscape. However, there are structural and management plans for the National Park of Kahuzi-Biega and the Natural Reserve of Tayna, and other plans are still underway.

\section{Institutional partners}

There are a number of institutions intervening in terms of nature conservation in the landscape. They include:

- $\quad \mathrm{Cl}$ (Conservation International)

- UMD-CARPE (University of Maryland - Central African Regional Program for Environment)

- $\quad$ OSFAC (Observatoire Satellital des forêts d'Afrique Centrale Satellite Observatory of Central African Forests)

- $\quad$ FORAF project (project on African Forests)

- $\quad$ IUCN (International Union for the Conservation of Nature)

- $\quad$ ICCN (Congolese Institute for the Conservation of Nature)

- US National Park Service

- GIZ (German International Cooperation)

- $\quad$ WWF (World Wildlife Fund for Nature)

- FFI (Fauna \& Flora International)

- UGADEC (Union of associations for the conservation of gorillas and community development in the eastern Democratic Republic of the Congo).

\section{Opportunities/Adaptation and REDD}

As far as knowledge about the REDD+ process (reducing emissions from deforestation and forest degradation in developing countries) and adaptation to climate change are concerned, much remains to be done. There is a lack of information, education and communication activities on the topic. Apart from the pilot project carried out with the help of Conservation International (Cl) in the Natural Reserve of Tayna by the Tayna Center for Conservation Biology with student involvement, activities seem to be at a standstill.

\section{Challenges}

Challenges include the sheer size of the landscape (10 million hectares), which has an impact on logistics, transport and communications (lack of infrastructure), and the existence of some unsafe areas. Access to the landscape can be via air, road or on foot, but the unstable situation with regard to safety in the region has to be factored in.

The region is also home to an ever-growing population, with densities ranging from 30 inhabitants per square kilometre in the east to 300 inhabitants per square kilometre in the west on the Gift Albertin mounts.

\section{Constraints}

In spite of the presence of numerous institutional partners in the landscape, the needs are still enormous, considering the challenges to be addressed. The greatest concerns are the conservation of biodiversity while respecting the development needs of local communities.

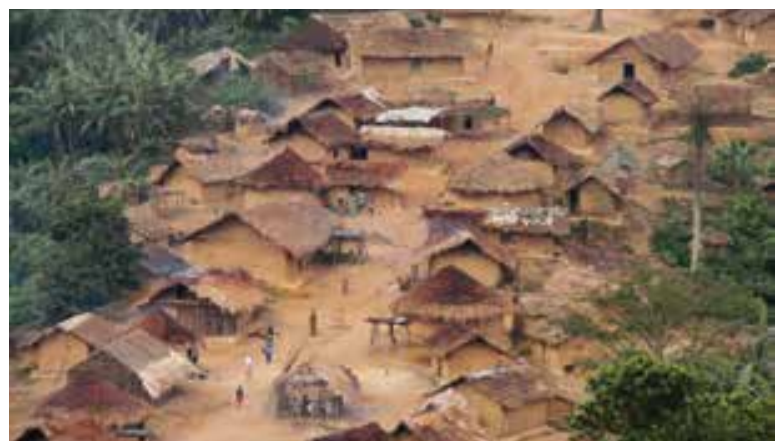

Poor and highly vulnerable housing in the landscape

Source: Staff at the National Park of Kahuzi-Biega, Congolese Wildlife Authority (ICCN-PNKB)

COBAM is implemented by CIFOR under the African Development Bank (AfDB) grant to the Economic Community of Central African States (ECCAS) for financing the Congo Basin Ecosystems Conservation Support Program (PACEBCo).
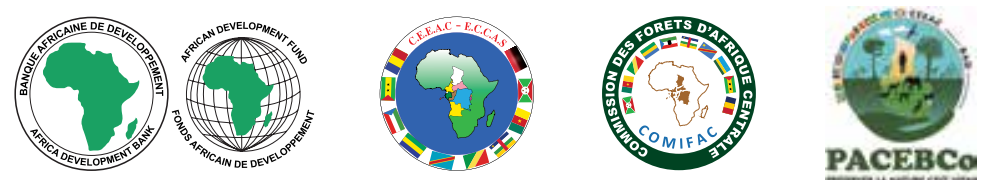

cifor.org/cobam

blog.cifor.org

Center for International Forestry Research

CIFOR advances human wellbeing, environmental conservation and equity by conducting research to inform policies and practices that affect forests in developing countries. CIFOR is a CGIAR Consortium Research Center. CIFOR's headquarters are in Bogor, Indonesia. It also has offices in Asia, Africa and South America. 